\title{
Rational Thinking on the Teaching of Chinese Piano Music in Colleges and Universities
}

\author{
Ping Wang \\ College of Music, Chengdu Normal University, Chengdu, Sichuan 611130, China. \\ wangping@cdnu.edu.cn
}

Keywords: Chinese piano music; higher education; folk music culture; piano education

\begin{abstract}
Chinese piano music not only possesses the artistic charm of piano, but also fuses the cultural tradition and artistic style of China for thousands of years. Here, we highlight the significance of establishing the consciousness of national music and inheriting the Chinese folk music for university students, and emphasize that Chinese piano music should be raised to an important position in higher music education. It would be helpful for students to understand and master the applications of western musical instruments in Chinese folk music, and learn more about and carry forward their excellent music culture.
\end{abstract}

\section{The Significance of Teaching Chinese Piano Music in Colleges and Universities}

Chinese folk music is one of the roots of the China national art [1]. The fusion of Chinese folk music with piano is an efficient way to extend the national culture of China and to promote the internationalization of Chinese art and culture to the world. However, at present, piano education in China is still dominated by the western piano teaching system. Students trained in modern music are not only educators in the traditional sense, but also the inheritors of music culture [2]. In piano music teaching, Chinese piano pieces should have a significant position in higher music education. The Chinese piano music, refined from folk phonology and sound of piano, would create a fantastic rhythm to be welcomed by the Chinese people and to enter into the piano classes of Chinese school [3]. With the rapid development of society, the artistic atmosphere is getting better and better in China. Chinese piano educators should inherit and carry forward Chinese piano music as their own task, adhering to the spirit of teaching and learning. Through hard work, the performance and teaching of Chinese piano music, and even the whole piano art career, are developing vigorously.

We should not reject any advanced culture, but at the same time absorbing the essence of western piano music. We also must combine the characteristics of our own culture and make it foreign use. China's 5000 years of culture has a long history and has affected the whole world. In turn, the development of world culture is exerting a subtle influence on China. The piano was originated in Europe, where there is a deep accumulation of piano music and art, and of course it is regarded as authentic. We have no reason to go behind the scenes. Instead, we should face the cultural tendency and fuse it with the Chinese folk music.

\section{The Current Status of Teaching Chinese Piano Music in Colleges and Universities}

For a long time, in people's traditional ideas the foreign things are always better than ours. It is also the result of "western musical instruments must to play western pieces", "the piano is not suitable to show Chinese music and folk art". The piano pieces of western composers have monopolized the performance and education of piano music. As a consequence, most people can teach or play well in foreign pieces, but do not know or even despise Chinese piano music [4]. In addition, there are no modern Chinese piano despise with distinctive characteristics as necessary teaching supplements, which makes many students even reluctant to play Chinese pieces. Although the creation of Chinese piano pieces has made a great progress in recent years, the academia has seldom carried out a systematic discussion about how to choose Chinese pieces in the piano teaching, which is not consistent with the current situation of the development of Chinese piano music.

For the selection of Chinese piano music as the piano teaching materials in normal university, we thinks that the number and proportion of Chinese piano pieces are very low as compared to that of western piano pieces at present. In addition, these pieces are commonly lack of systematicness and representativeness, 
which do not follow the principle of proceeding in an orderly way and step by step [5]. In China, there are very few higher normal teaching materials used in colleges and universities, such as "Piano Basic Course" and "Piano Tutorials". Both of the two courses have a small section introducing Chinese outstanding piano music, but the selection of Chinese piano etudes and polyphonic pieces is not sufficient and diverse; the arrangement of small and medium pieces is mainly based on the modified composition, such as the red head rope, the story of orchid flower, the open happiness of osmanthus, the mountain of running horses, and the folk songs of the Northern Shaanxi, but lacks of new era elements, and the content has only a limited cover of Chinese folk music, and the content is too single, especially in the piano basic course, the selected piano pieces is short and have only a low representativeness.

Of course, it is a very difficult thing to write a set of piano teaching materials for colleges and universities, not only to have foreign music, but also to have Chinese style, not only to highlight the development of the times, but also to inherit the classics; it is not only a matter of having various types of music and technical exercises, but also make its harmonious and balanced [6]. Alternatively, we can only to gradually improve it according to the current teaching needs.

At present, piano teachers in colleges and universities are also trained by western piano teaching system. These Chinese piano players, including our university piano teachers, are inevitable to face the fierce conflict between two distinct cultures and between two different aesthetics. If the idea of western culture and aesthetic are dominant in the teachers' mind, the cultural and aesthetic concepts of their own country will be largely suppressed and rejected. Because we don't pay enough attention to the choice and use of Chinese piano music, or do not pay enough attention to it from spirit, some teachers and students cannot well understand the differences between Chinese and western music culture, and thus are not accustomed to the piano music played in Chinese style, and even some teachers and students look down on the piano music created by Chinese composers.

Since the early 20th century, there have been a few of Chinese composers to create their own piano music. After accumulated efforts a considerable number of Chinese piano pieces have been recorded. The tune of excellent Chinese piano music adapted from and concerted with ancient music or folk songs. In order to experience the style and flavor of these pieces well, we should not only understand the traditional culture of Chinese people, but also absorb the nutrition from Chinese poetry, calligraphy and painting. In Chinese piano music, the "Chinese charm", "flavor", "tone features" and "artistic conception" are also inseparable from the national characteristics of our country and the humanistic nature of the Chinese.

\section{The Prospect of Promoting the Teaching of Chinese Piano Music in Colleges and Universities}

The following aspects should be taken to promote the development of piano teaching in colleges and universities:

(1) To promote the systematization of Chinese piano pieces and establish our own piano teaching system. In general, piano teaching includes basic exercises, etudes polyphony, small and medium music and large movements [7]. Therefore, Chinese piano pieces should also balance these aspects to create a compatible mode between them. Only through systematic training, one can annotate the Chinese piano music better. We should make the increased number of Chinese piano pieces at the beginning and intermediate levels and establish our own teaching system and teaching materials. On the basis of active creation of Chinese piano pieces, many aspects such as creation, publishing and teaching work can be collected together to solve a series of weak links and form a unified teaching system.

(2) Let every piano player touch as early as possible with the excellent Chinese piano music from the beginning of his learning. In recent years, our composers not only wrote a lot of piano pieces suitable for beginners, but also published some of children piano enlightenment textbooks. Although these children piano teaching materials are not diverse and limited, we can use them as foundational materials to train the piano beginners.

(3) Teaching and learning are complementary to each other. Teachers are directly facing the group of educated people, whose behavior should also directly affect students [8]. What kind of national music culture 
and aesthetic is suited for piano teachers in universities? From the understanding of the essence of our culture, we should thoroughly understand the Chinese piano music and strengthen the understanding and study of the relevant folk culture, such as life customs, local human feelings, historical background, natural landscape and so on. Full of national feelings and profound national tradition, we can understand, interpret and deduce Chinese piano music in a unique perspective.

(4) China is a country with a long history of civilization. It provides fertile soil for the creation of special folk music. The working people have created rich and colorful folk music in the long history. Chinese piano pieces are the extension of western music art and also an important part of our national culture [9]. We should combine teaching and playing to create more and better piano pieces with Chinese national characteristics. At the same time, we should also strengthen academic exchanges, convene academic discussions on various topics regarding the Chinese piano pieces, and promote the composing, teaching and playing of such pieces in university.

\section{Conclusion}

After the introduction of the piano from the west, it has obviously been nationalized. A large number of Chinese musicians use this traditional western musical instrument to create Chinese piano pieces with Chinese elements and folk characteristics, which is of great significance to the development of Chinese music and art. Through the integration of Chinese piano pieces in the piano teaching in colleges and universities, it is of great help to the change of students' piano learning concept and the improvement of playing skills. Therefore, the application of Chinese piano pieces to the piano teaching in colleges and universities should be paid attention by the piano teachers.

\section{Acknowledgment}

This work is supported by the CMCNU.

\section{References}

[1]. J. Jie, Chinese music. Cambridge: Cambridge University Press, 2011.

[2]. C.Wang, Chinese piano music culture. Beijing: Guangming Daily Publishing House, 2009.

[3]. Q. Guo, “The application of Chinese piano music in university piano teaching (In Chinese),” Literature Life, vol. 9, pp. 102, April, 2016.

[4]. D. Gu, “The importance of Chinese piano music in piano teaching (In Chinese),” Home Drama, vol. 23, pp. 207, June 2016.

[5]. X. Chen, “Chinese piano music taught in colleges and universities (In Chinese),” Music Space Time, vol. 8, pp. 92-93, January 2012.

[6]. S. Mao, and N. Ding, "On the important value of teaching Chinese piano music in higher education (In Chinese),” Art Science and Technology, vol. 12, pp. 12-13, March 2014.

[7]. Y. Fu, "Discussion on the teaching of Chinese piano music (In Chinese)," Science and Technology Information, vol. 6, pp. 183-185, June 2010.

[8]. R. Chen, "Memorization of piano music: a challenge for Chinese piano students,” Asian Social Science, vol. 3, pp. 112-117, February 2016.

[9]. C. Wang, "Professional piano education in Chinese piano music culture," International Education Studies, vol. 1, pp. 92-95, March 2010. 